\title{
SISTEM PENDUKUNG KEPUTUSAN PEMILIHAN PTS DI LHOKSEUMAWE MENGGUNAKAN METODE FUZZY AHP BERBASIS WEB
}

\author{
Nurdin $^{\# 1}$, Miranda ${ }^{\# 2}$ \\ ${ }^{\# 1,2}$ Program Studi Teknik Informatika Fakultas Teknik Universitas Malikussaleh, Aceh \\ E-mail : nurdin_um@ymail.com
}

\begin{abstract}
Abstrak
Sistem Pendukung Keputusan pemilihan PTS ini bertujuan untuk memberikan dukungan pengambilan keputusan untuk pemilihan sebuah PTS di Lhokseumawe. Pada sistem ini terdapat 11 alternatif perguruan tinggi swasta dan ada 6 kriteria yang digunakan oleh sistem. Sistem ini menggunakan metode fuzzy untuk kriteriayang bobot nilainya tidak tetap, kriteria tersebut diantaranya jumlah lulusan, Jarak dengan kota, Biaya pendidikan, jumlah dosen dan pendidikan dosen serta menggunakan metode Analytic Hierarchy Process (AHP) yaitu untuk perangkingan Perguruan Tinggi yang dipilih oleh user. Pemberian nilai fuzzy berlaku untuk setiap kriteria yang ada. Pada sistem ini juga terdapat 2 proses yakni proses pemilihan perguruan tinggi swasta dan proses membandingkan tingkat kepentingan antar kriteria. Perhitungan fuzzy pada sistem ini tidak dilakukan di dalam sistem melainkan di input oleh admin sistem yang telah dicari terlebih dahulu nilai fuzzy kriteria untuk tiap alternatif yang ada. Hasil dari proses fuzzy dan AHP dalam aplikasi ini akan menghasilkan perangkingan untuk alternatif yang dipilih oleh user.
\end{abstract}

Kata kunci : Fuzzy, AHP, SPK, Pemilihan

\section{PENDAHULUAN}

Kebutuhan akan tenaga kerja professional dari hari ke hari semakin bertambah. Oleh sebab itu banyak PTS (Perguruan Tinggi Swasta) di Kota Lhokseumawe yang berlomba-lomba untuk membuka jurusan atau program studi yang dapat memberikan pengetahuan dan kemampuan yang dibutuhkan di dunia kerja sehingga nanti lulusan dari PTS dapat bersaing dengan lulusan PTN dan tenaga kerja lainnya.

Banyak dari kalangan siswa terutama siswa SMA kelas 3 yang sudah jauh-jauh hari mempersiapkan diri dengan mengikuti bimbingan belajar untuk masuk ke perguruan tinggi yang mereka inginkan. Tapi banyaknya perguruan tinggi saat ini juga membuat para siswa bingung dalam memilih perguruan tinggi mana yang cocok untuk mereka. Para siswa biasanya akan mencari informasi-informasi perguruan tinggi lewat internet, brosur, maupun datang langsung ke perguruan tinggi yang bersangkutan. Hal itu tentu belum bisa membuat siswa langsung bisa menetapkan perguruan tinggi mana yang akan mereka pilih dan tentu hal itu membuang waktu.

Banyak hal yang dipikirkan oleh siswa dalam menentukan perguruan tinggi mana yang akan mereka pilih. Para siswa tentu memiliki kriteria-kriteria tertentu untuk memilih perguruan tinggi, seperti biaya perkuliahan, lokasi, lingkungan perkuliahan, UKM yang dapat membantu dalam hal penyaluran bakat/hobi dan masih banyak kriteria lain yang biasanya dijadikan patokan dalam pemilihan sebuah PTS oleh siswa.

Proses pemilihan perguruan tinggi bagi siswa merupakan proses yang rumit dan mungkin mereka akan membuat kesalahan dalam pemilihan perguruan tinggi yang pada akhirnya membuat mereka menyesal dan menyusahkan bagi mereka. Untuk memperoleh informasi yang cepat dan hampir akurat akan pemilihan perguruan tinggi yang tepat dibutuhkan suatu proses otomatisasi dengan menggunakan teknologi. Oleh karena itu kebutuhan sebuah sistem yang berbasis komputer dirasa sangat perlu guna memenuhi kebutuhan informasi tersebut. 


\section{METODE PENELITIAN}

Metodelogi penelitian yang dilakukan dalam penelitian ini adalah sebagai berikut:

1. Teknik pengumpulan data

a. Studi kepustakaan

Studi Kepustakaan, dilakukan dengan cara mengumpulkan dan membaca serta memahami referensi yang terkait mengenai sistem pendukung keputusan pemilihan perguruan tinggi swasta juga mengumpulkan teori-teori dari beberapa sumber seperti buku perpustakaan, artikel dari internet, jurnal, dan referensi dari tugas akhir mahasiswa yang berkenaan dengan metode fuzzy AHP.

b. Wawancara

Pengambilan data melalui wawancara/secara lisan langsung dengan sumber datanya melalui tatap muka. Jawaban dari responden dirangkum sendiri oleh peneliti.

2. Analisa sistem

Peneliti menganalisa permasalahan-permasalahan yang ada di dalam proses pemilihan perguruan tinggi swasta dan melakukan pemahaman terhadap permasalahan tersebut sebelum mengambil tindakan atau keputusan penyelesaian akhir.

3. Merancang program aplikasi

Pada tahapan ini penulis melakukan perancangan sebuah aplikasi/program. Disini penulis merancang program agar dapat menyelesaikan sistem pendukung keputusan pemilihan perguruan tinggi swasta dengan menggunakan metode Fuzzy AHP berbasis Web. Langkah pertama dalam perancangan program ini adalah merancang proses kerja sistem dengan menggunakan DFD yang menjelaskan secara rinci proses-proses yang akan dilakukan program dalam menghasilkan sebuah keputusan. Selanjutnya merancang bentuk tampilan program (User Interface).

4. Melakukan pengujian program/testing

Tahapan akhir adalah melakukan debugging atau testing program dalam hal ini penulis melakukan serangkaian tes terhadap program yang telah dibuat. Test program bertujuan untuk mendapatkan kesalahan-kesalahan (trouble) sehingga kesalahan dapat segera diperbaiki.

\section{HASIL DAN PEMBAHASAN}

\subsection{Analisa Sistem Lama}

Dalam proses perancangan sistem yang berbasis komputer, analisis masalah memegang peranan penting dalam membuat rincian aplikasi yang akan dikembangkan, analisis masalah merupakan langkah pemahaman persoalan sebelum mengambil tindakan atau keputusan penyelesaian akhir.

Selama ini calon mahasiswa/i merasa masih minim dalam hal memperoleh informasi mengenai

PTS. Mereka mengalami kesulitan untuk memilih PTS yang sesuai dengan kriteria mereka sendiri. Dengan dukungan sistem ini, diharapkan dapat memberikan pengalaman baru bagi calon mahasiswa/i dalam memilih PTS.

\subsection{Desain Sistem}

\subsubsection{Deskripsi Pengguna}

Sistem yang akan dibangun terdiri dari beberapa tingkatan pengguna yang masing-masing memiliki hak akses yang berbeda. Beberapa tingkatan pengguna yang ada di dalam sistem ini adalah sebagai berikut :

1. User

User merupakan pengguna utama dalam sistem ini. Dimana user dapat memilih dan membandingkan lebih dari 3 PTS yang ada di dalam sistem. Seteleah user membandingkan PTS tersebut 
maka user akan memperoleh hasil berupa perangkingan PTS berdasarkan metode fuzzy ahp. Dalam sistem ini user adalah calon mahasiswa/i yang ingin masuk ke sebuah PTS.

2. Admin

Admin merupakan pengguna tingkatan tertinggi dalam sistem ini. Hak akses yang dimiliki oleh admin adalah sebagai berikut :

a. Mengelola data PTS

b. Mengelola data jurusan

c. Membandingkan PTS

\subsection{Desain Logika}

Berikut rancangan desain logika yang digunakan dalam rancangan Sistem Pendukung Keputusan Pemilihan PTS di Lhokseumawe menggunakan metode Fuzzy AHP berbasis web.

\subsubsection{Diagram Konteks}

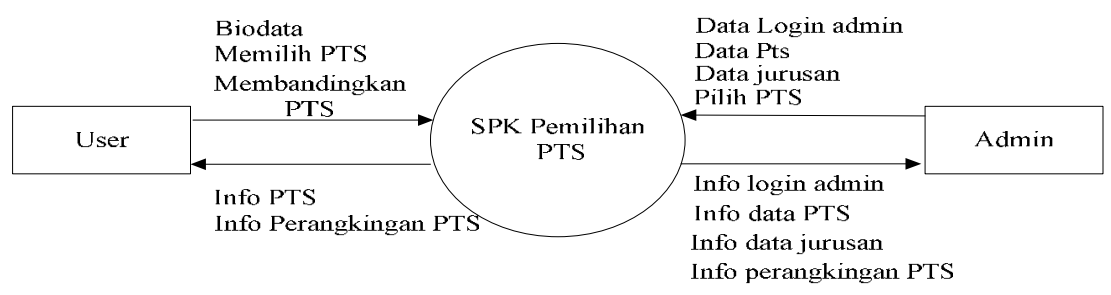

Gambar 1. Diagram Konteks

\subsubsection{Data Flow Diagram Level 0}

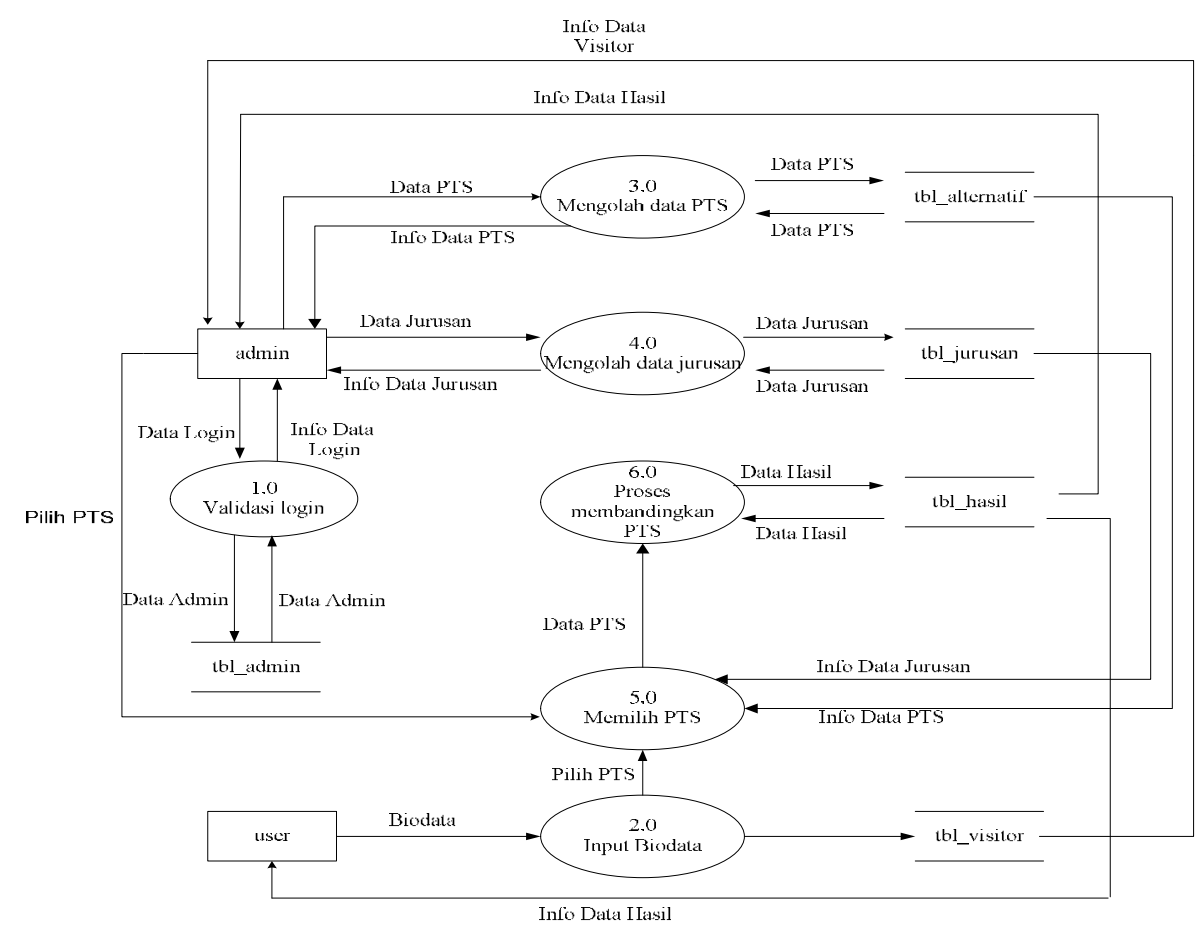

Gambar 2. DFD level 0 


\subsection{PENCARIAN MANUAL METODE FUZZY AHP}

\subsubsection{Nilai Fuzzy}

Keterangan:

A1 = STIKES Muhammadiyah Lhokseumawe

A2 $=$ STIKES Bumi Persada Lhokseumawe

A3 = STIE Bumi Persada Lhokseumawe

A4 = STIKES Darussalam Lhokseumawe

A5 $=$ Sekolah Tinggi Ilmu Ekonomi Lhokseumawe

A6 = STMIK Bina Bangsa

A7 $=$ Sekolah Tinggi Ilmu Administrasi Nasional

A8 = Akademi Kebidanan Darussalam

A9 = AKPER Kesdam Iskandar Muda Lhokseumawe

A10 $=$ Akademi Sekretari Manajemen Tanah Rencong

A11= Universitas Almuslim Kampus B Cunda

Tabel 1. Tabel Perhitungan Fuzzy

\begin{tabular}{|c|c|c|c|c|c|}
\hline Alternatif & $\begin{array}{l}\text { Jumlah } \\
\text { Lulusan }\end{array}$ & Jarak dg Kota & SPP/Semester & $\begin{array}{l}\text { Jumlah } \\
\text { Dosen }\end{array}$ & $\begin{array}{l}\text { Pendidikan } \\
\text { Dosen (S2) }\end{array}$ \\
\hline \multirow[b]{2}{*}{ A1 } & $205-100$ & $10 \mathrm{Km}-1.3 \mathrm{Km}$ & 3 juta -2.5 juta & $51-20$ & $11-5$ \\
\hline & $\begin{array}{l}\overline{7000-100} \\
=0.01\end{array}$ & $\begin{array}{l}10 \mathrm{Km}-1 \mathrm{Km} \\
=0.97\end{array}$ & $\begin{array}{l}\text { 3juta }-500 \text { ribu } \\
=0.2\end{array}$ & $\begin{array}{l}\overline{500-20} \\
=0.06\end{array}$ & $\begin{array}{l}200-5 \\
=0.03\end{array}$ \\
\hline \multirow[b]{2}{*}{$\mathrm{A} 2$} & $400-100$ & $10 \mathrm{Km}-8 \mathrm{Km}$ & 3 juta -2.2 juta & $40-20$ & $28-5$ \\
\hline & $\begin{array}{l}\overline{7000-100} \\
=0.04\end{array}$ & $\begin{array}{l}\overline{10 \mathrm{Km}-1 \mathrm{Km}} \\
=0.22\end{array}$ & $\begin{array}{l}\text { 3juta - 500ribu } \\
=0.32\end{array}$ & $\begin{array}{l}500-20 \\
=0.04\end{array}$ & $\begin{array}{l}200-5 \\
=0.11\end{array}$ \\
\hline \multirow[b]{2}{*}{ A3 } & $346-100$ & $10 \mathrm{Km}-7.7 \mathrm{Km}$ & 3 juta -900 ribu & $47-20$ & $26-5$ \\
\hline & $\begin{array}{l}\overline{7000-100} \\
=0.03\end{array}$ & $\begin{array}{l}10 \mathrm{Km}-1 \mathrm{Km} \\
=0.25\end{array}$ & $\begin{array}{l}\text { 3juta }-500 \text { ribu } \\
=0.84\end{array}$ & $\begin{array}{l}500-20 \\
=0.05\end{array}$ & $\begin{array}{l}200-5 \\
=0.10\end{array}$ \\
\hline \multirow[b]{2}{*}{ A4 } & $877-100$ & $10 \mathrm{Km}-1.4 \mathrm{Km}$ & 3 juta -2.5 juta & $137-20$ & $47-5$ \\
\hline & $\begin{array}{l}\overline{7000-100} \\
=0.11\end{array}$ & $\begin{array}{l}10 \mathrm{Km}-1 \mathrm{Km} \\
=0.95\end{array}$ & $\begin{array}{l}\text { juta - 500ribu } \\
=0.2\end{array}$ & $\begin{array}{l}\overline{500-20} \\
=0.24\end{array}$ & $\begin{array}{l}200-5 \\
=0.21\end{array}$ \\
\hline \multirow[b]{2}{*}{ A5 } & $187-100$ & $10 \mathrm{Km}-2.4 \mathrm{Km}$ & 3 juta -1.5 juta & $26-20$ & $8-5$ \\
\hline & $\begin{array}{l}\overline{7000-100} \\
=0.01\end{array}$ & $\begin{array}{l}\overline{10 \mathrm{Km}-1 \mathrm{Km}} \\
=0.84\end{array}$ & $\begin{array}{l}\text { 3 juta }-500 \text { ribu } \\
=0.6\end{array}$ & $\begin{array}{l}\overline{500-20} \\
=0.01\end{array}$ & $\begin{array}{l}200-5 \\
=0.01\end{array}$ \\
\hline \multirow[b]{2}{*}{ A6 } & $910-100$ & $10 \mathrm{Km}-2.9 \mathrm{Km}$ & 3 juta -1.2 juta & $24-20$ & $20-5$ \\
\hline & $\begin{array}{l}\overline{7000-100} \\
=0.11\end{array}$ & $\begin{array}{l}10 \mathrm{Km}-1 \mathrm{Km} \\
=0.79\end{array}$ & $\begin{array}{l}\text { 3juta }-500 \text { ribu } \\
=0.72\end{array}$ & $\begin{array}{l}\overline{500-20} \\
=0.008\end{array}$ & $\begin{array}{l}200-5 \\
=0.07\end{array}$ \\
\hline \multirow[b]{2}{*}{ A7 } & $567-100$ & $10 \mathrm{Km}-2.4 \mathrm{Km}$ & 3 juta -1.2 juta & $23-20$ & $21-5$ \\
\hline & $\begin{array}{l}\overline{7000-100} \\
=0.06\end{array}$ & $\begin{array}{l}\overline{10 \mathrm{Km}-1 \mathrm{Km}} \\
=0.84\end{array}$ & $\begin{array}{l}\overline{3 \text { juta }-500 \text { ribu }} \\
=0.72\end{array}$ & $\begin{array}{l}\overline{500-20} \\
=0.006\end{array}$ & $\begin{array}{l}200-5 \\
=0.08\end{array}$ \\
\hline \multirow[b]{2}{*}{ A8 } & $782-100$ & $10 \mathrm{Km}-1.4 \mathrm{Km}$ & 3 juta -2 juta & $44-20$ & $27-5$ \\
\hline & $\begin{array}{l}\overline{7000-100} \\
=0.09\end{array}$ & $\begin{array}{l}10 \mathrm{Km}-1 \mathrm{Km} \\
=0.95\end{array}$ & $\begin{array}{l}\overline{3 \text { juta }-500 \text { ribu }} \\
=0.4\end{array}$ & $\begin{array}{l}\overline{500-20} \\
=0.05\end{array}$ & $\begin{array}{l}200-5 \\
=0.11\end{array}$ \\
\hline \multirow[b]{2}{*}{ A9 } & $300-100$ & $10 \mathrm{Km}-1.8 \mathrm{Km}$ & 3 juta -2.1 juta & $30-20$ & $11-5$ \\
\hline & $\begin{array}{l}\overline{7000-100} \\
=0.02\end{array}$ & $\begin{array}{l}10 \mathrm{Km}-1 \mathrm{Km} \\
=0.91\end{array}$ & $\begin{array}{l}\text { juta }-500 \text { ribu } \\
=0.36\end{array}$ & $\begin{array}{l}\overline{500-20} \\
=0.02\end{array}$ & $\begin{array}{l}200-5 \\
=0.03\end{array}$ \\
\hline
\end{tabular}




\begin{tabular}{|c|c|c|c|c|c|}
\hline A 10 & $\begin{array}{l}\frac{335-100}{7000-100} \\
=0.03\end{array}$ & $\begin{array}{l}\frac{10 \mathrm{Km}-1.5 \mathrm{Km}}{10 \mathrm{Km}-1 \mathrm{Km}} \\
=0.94\end{array}$ & $\begin{array}{l}\frac{3 \text { juta }-700 \text { ribu }}{3 \text { juta }-500 \mathrm{ribu}} \\
=0.92\end{array}$ & $\begin{array}{l}\frac{21-20}{500-20} \\
=0.002\end{array}$ & $\begin{array}{l}\frac{6-5}{200-5} \\
=0.005\end{array}$ \\
\hline A11 & $\begin{array}{l}\frac{6892-100}{7000-100} \\
=0.98\end{array}$ & $\begin{array}{l}\frac{10 \mathrm{Km}-2.3 \mathrm{Km}}{10 \mathrm{Km}-1 \mathrm{Km}} \\
=0.85\end{array}$ & $\begin{array}{l}\frac{3 \text { juta }-1.1 \text { juta }}{3 \text { juta }-500 \text { ribu }} \\
=0.76\end{array}$ & $\begin{array}{l}\frac{489-20}{500-20} \\
=0.97\end{array}$ & $\begin{array}{l}\frac{134-5}{200-5} \\
=0.66\end{array}$ \\
\hline
\end{tabular}

3.4.2 Menetapkan Nilai Perbandingan Berpasangan

Tabel 2. Tabel Perbandingan Berpasangan

\begin{tabular}{|c|c|c|c|c|c|c|}
\hline & K1 & K2 & K3 & K4 & K5 & K6 \\
\hline K1 & 1 & 5 & 5 & 5 & 3 & 3 \\
\hline K2 & 0.2 & 1 & 1 & 1 & $1 / 3$ & $1 / 3$ \\
\hline K3 & 0.2 & 1 & 1 & 1 & $1 / 3$ & $1 / 3$ \\
\hline K4 & 0.2 & 1 & 1 & 1 & $1 / 3$ & $1 / 3$ \\
\hline K5 & 0.333333 & 3 & 3 & 3 & 1 & 1 \\
\hline K6 & 0.333333 & 3 & 3 & 3 & 1 & 1 \\
\hline
\end{tabular}

\subsubsection{Bobot Prioritas Kriteria}

Tabel 3. Tabel Bobot Prioritas Kriteria

\begin{tabular}{|c|c|c|c|c|c|c|c|}
\hline & $\mathrm{K} 1$ & $\mathrm{~K} 2$ & $\mathrm{~K} 3$ & $\mathrm{~K} 4$ & $\mathrm{~K} 5$ & $\mathrm{~K} 6$ & tot.baris \\
\hline $\mathrm{K} 1$ & 0.44 & 0.36 & 0.36 & 0.36 & 0.50 & 0.50 & $\mathbf{0 . 4 2}$ \\
\hline $\mathrm{K} 2$ & 0.09 & 0.07 & 0.07 & 0.07 & 0.06 & 0.06 & $\mathbf{0 . 0 7}$ \\
\hline $\mathrm{K} 3$ & 0.09 & 0.07 & 0.07 & 0.07 & 0.06 & 0.06 & $\mathbf{0 . 0 7}$ \\
\hline K4 & 0.09 & 0.07 & 0.07 & 0.07 & 0.06 & 0.06 & $\mathbf{0 . 0 7}$ \\
\hline K5 & 0.15 & 0.21 & 0.21 & 0.21 & 0.17 & 0.17 & $\mathbf{0 . 1 9}$ \\
\hline K6 & 0.15 & 0.21 & 0.21 & 0.21 & 0.17 & 0.17 & $\mathbf{0 . 1 9}$ \\
\hline total & $\mathbf{0 . 8 5}$ & $\mathbf{0 . 7 9}$ & $\mathbf{0 . 7 9}$ & $\mathbf{0 . 7 9}$ & $\mathbf{0 . 8 3}$ & $\mathbf{1 . 0 0}$ & $\mathbf{0 . 8 4}$ \\
\hline
\end{tabular}

\subsubsection{Konsistensi Kriteria}

Tabel 4. Tabel Konsistensi Kriteria

\begin{tabular}{|c|c|c|c|c|c|c|c|c|}
\hline & K1 & K2 & K3 & K4 & K5 & K6 & X & \\
\hline K1 & 1 & 5 & 5 & 5 & 3 & 3 & 0.42 & $\mathbf{2 . 5 8}$ \\
\hline K2 & 0.2 & 1 & 1 & 1 & $1 / 3$ & $1 / 3$ & 0.07 & $\mathbf{0 . 4 2}$ \\
\hline K3 & 0.2 & 1 & 1 & 1 & $1 / 3$ & $1 / 3$ & 0.07 & $\mathbf{0 . 4 2}$ \\
\hline K4 & 0.2 & 1 & 1 & 1 & $1 / 3$ & $1 / 3$ & 0.07 & $\mathbf{0 . 4 2}$ \\
\hline K5 & 0.333333 & 3 & 3 & 3 & 1 & 1 & 0.19 & $\mathbf{1 . 1 3}$ \\
\hline K6 & 0.333333 & 3 & 3 & 3 & 1 & 1 & 0.19 & $\mathbf{1 . 1 3}$ \\
\hline
\end{tabular}




\subsubsection{Hitung lamda maksimum}

$$
\begin{aligned}
\lambda \text { maks } & =(2.58+0.42+0.42+0.42+1.13+1.13) / 6 \\
& =6.09 / 6 \\
& =1.01519 \\
& =(\lambda \text { Maksimum }-\mathrm{n}) /(\mathrm{n}-1) \\
& =(1.01519-6) /(6-1) \\
& =-0.99696 \\
& =-0.99696 / 1.24 \\
\text { Hitung CI } & =-0.804
\end{aligned}
$$

Oleh karena nilai $\mathrm{CR}<0,1$ maka rasio konsistensi perhitungan dapat diterima.

\subsection{Output Sistem}

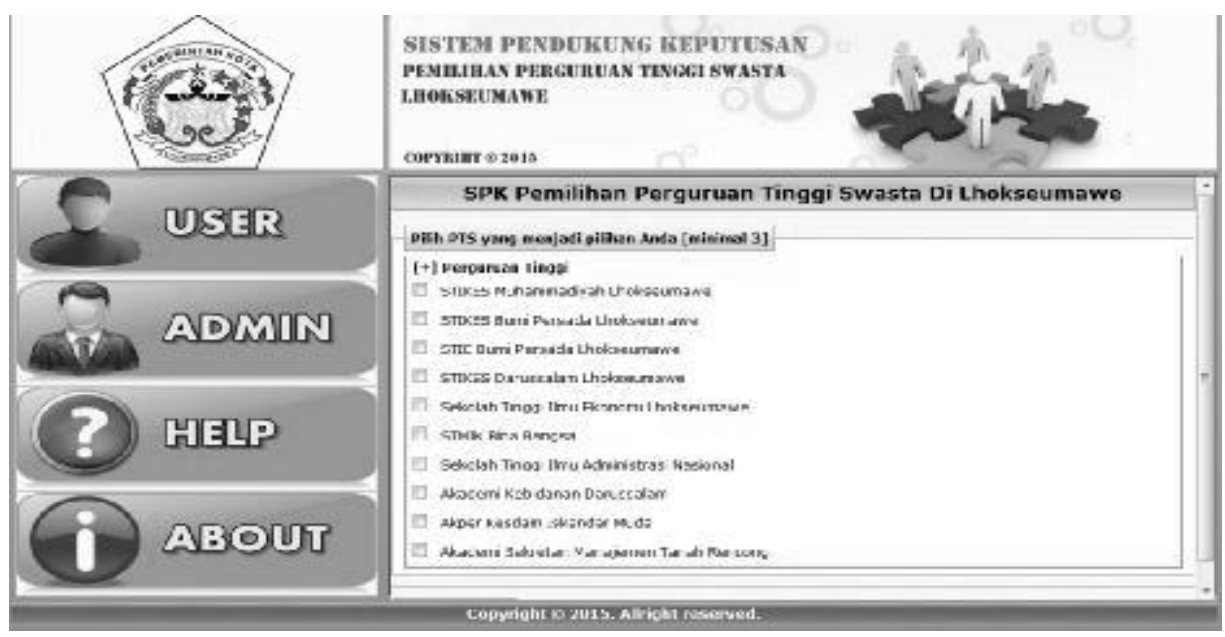

Gambar 3. Tampilan Form memilih PTS

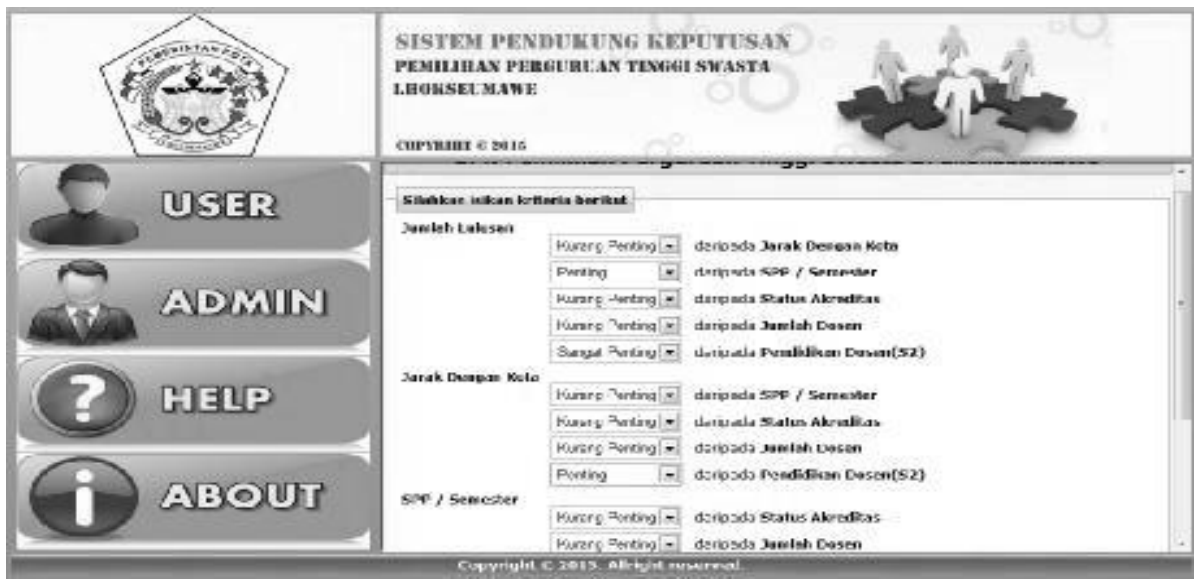

Gambar 4. Form Menentukan Bobot Kriteria 


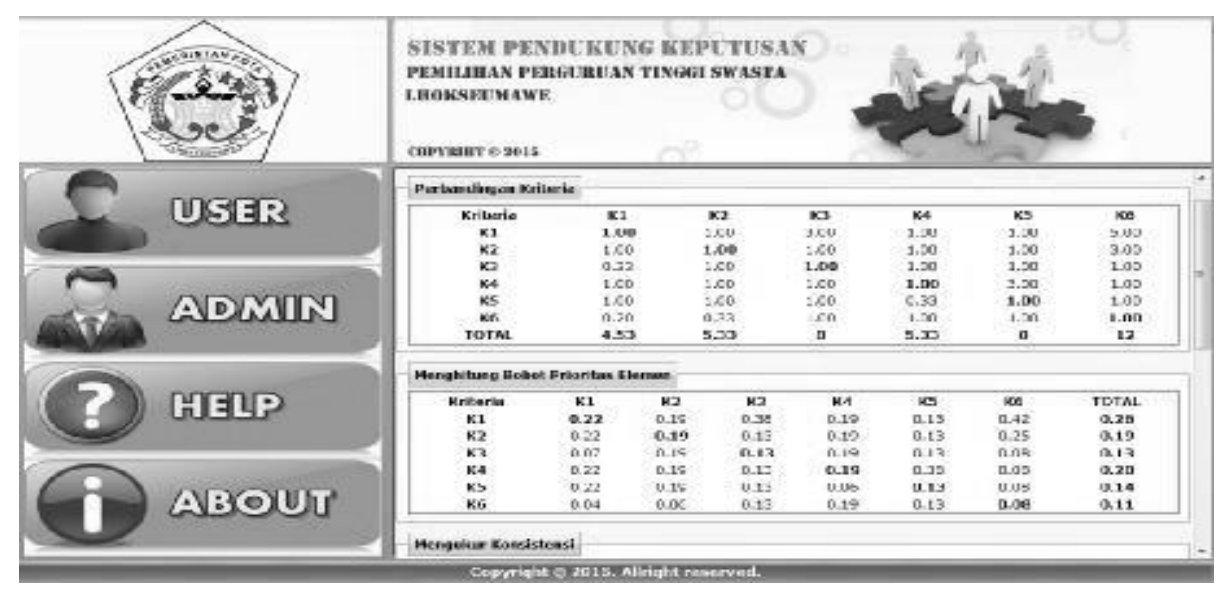

Gambar 5. Form hasil perhitungan

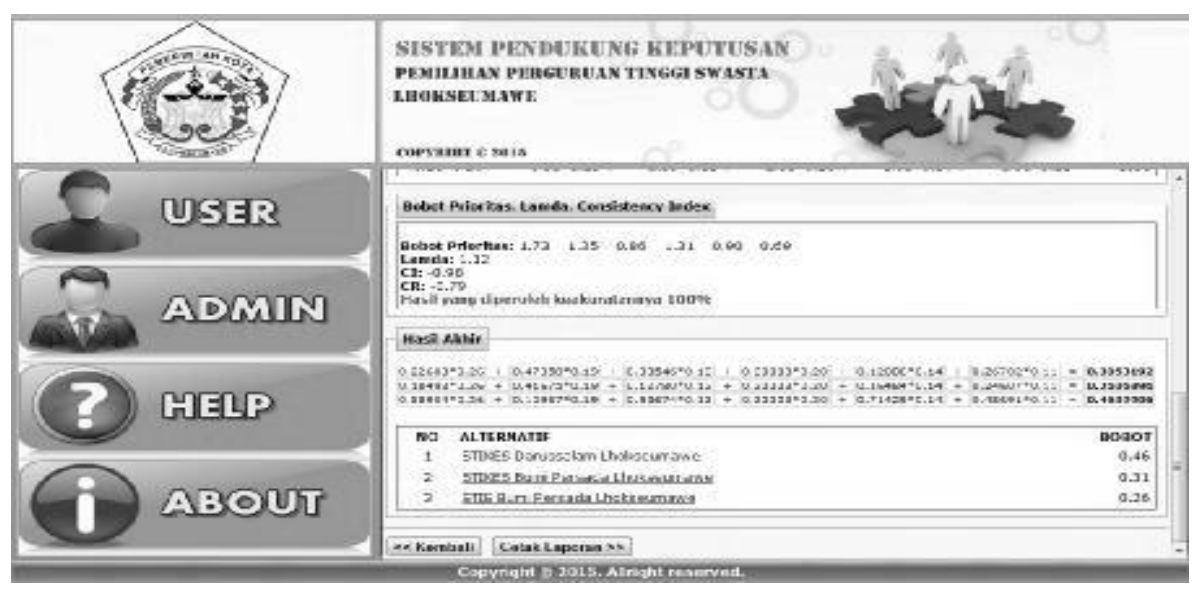

Gambar 6. Form hasil Akhir 


\begin{tabular}{|c|c|c|c|c|}
\hline \multicolumn{5}{|c|}{ DAFTAR PERGURUAN TINGGI SWASTA YANG ANDA PILIH } \\
\hline \multicolumn{2}{|c|}{ Nams Lengless } & \multicolumn{3}{|c|}{ is Sarnil Rarrathan } \\
\hline \multicolumn{2}{|l|}{ Alamet } & \multicolumn{3}{|c|}{ : Batuphat } \\
\hline \multicolumn{2}{|c|}{ asal Sekniah } & \multicolumn{3}{|c|}{ : 5 ma I Lanpsa } \\
\hline Ma & Bohot & Peringleat & pis & Jurusan Yane Ada \\
\hline 1 & 1.27 & 1 & Akademi Kebidaran Darussalim & 1. DJ-katudaran \\
\hline 2 & 1.22 & 2 & STIE Bumi Persada Lhokseumawe. & $\begin{array}{l}\text { 1. \$1- Ekonomi Abantara } \\
\text { 2. \$1-Ekonomi Manzidemen }\end{array}$ \\
\hline 3 & 0.57 & 3 & Sekolah Thog Dro Economithokseumene & $\begin{array}{l}\text { 1. S1-Ekonomi Akuntans } \\
\text { 2. S1-Ekonomi Pembangunan }\end{array}$ \\
\hline \multicolumn{2}{|c|}{ Nama Lengkap } & \multicolumn{3}{|c|}{ : Ani } \\
\hline \multicolumn{2}{|l|}{ Alamat } & \multicolumn{3}{|c|}{ : Medan } \\
\hline \multicolumn{2}{|c|}{ Assi Sekoloh } & \multicolumn{2}{|c|}{ : SMAN 20} & \\
\hline No & Bobot & Peringlat & PTs & Jerusan Yang Ado \\
\hline 1 & 1.18 & 1 & STIE Bumi Persada Lhokseumawe & $\begin{array}{l}\text { 1. S1-Eksnom Akurtans } \\
\text { 2. S1-Ekonom Manstaren }\end{array}$ \\
\hline 2 & 1.13 & 2 & Akedem Kebidanan Darussalam & 1. 03-Kebitaman \\
\hline 3 & 0.98 & 3 & STDKES Huharmadich Lhoksaumawe & $\begin{array}{l}\text { 1. D.-Koparawatan } \\
\text { 2. Narf } \\
\text { 3. S1-Keperawatan }\end{array}$ \\
\hline 4 & 0.79 & 4 & Saloclah Tingo tiru Ndimistral Nadonal & 1. 51-timu Adrinstras Nagara \\
\hline
\end{tabular}

Gambar 7. Form cetak semua laporan

\section{KESIMPULAN}

1. Sistem Pendukung Keputusan Pemilihan Perguruan Tinggi Swasta merupakan sebuah sistem yang dapat menentukan perguruan tinggi mana yang akan di pilih oleh calon mahasiswa dimana dalam melakukan proses pengambilan keputusan menggunakan metode fuzzy AHP.

2. Sistem ini menggunakan metode fuzzy untuk mem-fuzzy kriteria-kriteria yang bobot nilainya tidak tetap, kriteria tersebut di antaranya Jumlah Lulusan, Jarak Dengan Kota, Biaya Pendidikan, Jumlah Dosen, dan Pendidikan Dosen(S2).

3. Sistem ini juga menggunakan metode Analytic Hierarchy Process (AHP) yaitu untuk perangkingan Perguruan Tinggi yang dipilih oleh user/pengguna.

4. Dengan adanya sistem ini maka calon mahasiswa dapat membandingkan Perguruan Tinggi Swasta yang di pilih lebih dari 3 dan akan menampilkan hasil berdasarkan penilaian terhadap kriteria yang di bandingkan sendiri oleh calon mahasiswa itu sendiri.

5. Sistem ini menampilkan nama Perguruan Tinggi Swasta mana yang akan dijadikan pertimbangan dalam pengambilan keputusan oleh calon mahasiswa.

\section{SARAN}

1. Sistem pendukung keputusan ini dibangun dengan menggunakan metode fuzzy AHP, akan lebih baik apabila sistem ini dicoba dengan menggunakan metode yang lain sehingga dapat diketahui kekurangan dan kelebihan dari masing-masing metode.

2. Perancangan berikutnya diharapkan dapat menyempurnakan bagian desain agar tampak lebih menarik. 


\section{DAFTAR PUSTAKA}

Bella. 2014. Sistem Pendukung Keputusan Penentuan Golongan UKT (Uang Kuliah Tunggal) Dengan Menggunakan Metode Fuzzy Topsis [Skripsi]. Jurusan Teknik Informatika. Universitas Malikussaleh.

Magdalena, Hilyah. 2012. Sistem Pendukung Keputusan Untuk Menentukan Mahasiswa Lulusan Terbaik Di Perguruan Tinggi (Studi Kasus Stmik Atma Luhur Pangkalpinang). STMIK Atma Luhur Pangkalpinang. Yogyakarta.

Republik Indonesia. 2012. Undang-Undang Republik Indonesia Nomor 12 Tahun 2012 Tentang Pendidikan Tinggi.

Sutabri, Tata. 2012. Analisis Sistem Informasi. Andi Offset. Yogyakarta.

Sidik, Betha. 2014. Pemrograman Web Dengan Php. Edisi Revisi Kedua. Informatika. Bandung

Saragih, Silviahartati. 2013. Sistem Penerapan Metode Analitycalhierarchy Process (Ahp) Pada Sistempendukung Keputusan Pemilihan Laptop. STMIK Budi Darma. Medan.

Wigati, Erni. 2012. Perancangan Website Sekolah Menengah Pertama Negeri 262 Cakung Jakarta Timur Dengan Menggunakan Php Dan Mysql. Gunadarma University. Jakarta. 